\title{
Model Pembangunan Kawasan Perbatasan Kalimantan Utara Yang Berpihak Pada Masyarakat Hukum Adat
}

\author{
Marthen B Salinding, Basri \\ Universitas Borneo Tarakan \\ Email:mhukum@ymail.com
}

\begin{abstract}
The North Kalimantan Border Area is largely inhabited by indigenous peoples. Development of Border Areas is a necessity, because the development of border areas is part of national development. Indigenous peoples in the border region have the character and local wisdom that determines with other communities, so that the development model in other regions does not necessarily show partiality to the indigenous peoples in the border region. There are two questions in this study; first, regarding the characteristics of the border problems of North Kalimantan Province and their implications for indigenous peoples,? and secondly; Does the development model in the border area favor indigenous peoples?

This type of research is normative juridical research, with qualitative analysis. The research objective to be achieved is to produce an appropriate development model applied in areas that connect to the copyright of indigenous peoples in the border region, and produce specific findings for. Reducing legal and policy barriers in finding development models in the border region in North Kalimantan that favor the indigenous peoples.

Keywords; Models, development, indigenous peoples, borders
\end{abstract}

\section{Pendahuluan.}

Kawasan Perbatasan Kalimantan Utara sebagian besar dihuni oleh masyarakat hukum adat. Pembangunan Kawasan Perbatasan adalah sebuah keniscayaan, karena pembangunan kawasan perbatasan merupakan bagian dari pembangunan Nasional. Masyarakat hukum adat di kawasan perbatasan meliki karakter dan kearifan lokal yang membedakan dengan masyarakat lainnya, sehingga model pembangunan di daerah lain belum tentu menunjukkan keberpihakan kepada masyarakat hukum adat di kawasan perbatasan

Model pembangunan kawasan perbatasan dalam beberapa tahun terakhir telah menjadi isu yang santer dibicarakan dalam berbagai kesempatan, mulai dari rapat-rapat terbatas dan koordinasi antar kementerian/instansi pusat dan daerah, seminar, lokakarya, pembahasan di DPR, sampai ke sidang kabinet. Maraknya pembicaraan masalah perbatasan 
ini sebenarnya telah dimulai sejak dulu. Terutama sejak dibukanya pintu perbatasan (border gate) di beberapa titik di Kalimantan, yang ternyata telah memperlihatkan kepada masyarakat Indonesia, khususnya masyarakat hukum adat di sekitar perbatasan dan masyarakat Indonesia pada umumnya, bahwa ada kesenjangan sosial, ekonomi dan kesejahteraan antara masyarakat hukum adat perbatasan di Indonesia dan di Malaysia.

Masuknya perusahaan-perusahaan pertambangan batubara, perusahaan perkebunan kelapa sawit dan Hak Pengelolaan Hutan (HPH) di Kawasan Perbatasan Kalimantan Utara untuk mengelola sumber daya alam adalah konsekwensi dari kebijakan negara mengoptimalisasi pemanfaatan sumber daya alam, pada satu sisi akan meningkatkan pertumbuhan perekonomian daerah dan peningkatan kesejahteraan masyarakat, namun pada sisi lainnya mengerus hak-hak masyarakat hukum adat terhadap tanah ulayat dan sumberdaya alam. Masalah muncul karena masyarakat hukum adat telah lama menempati, menguasai dan/atau mengusahakan tanah ulayat untuk memenuhi kebutuhan hidupnya secara turun temurun. Namun atas nama penguasaan negara atas bumi, air, dan kekayaan alam yang terkandung di dalamnya sebagaimana diatur dalam Pasal 33 ayat (3) UUD Tahun 1945, pemerintah memberikan ijin (konsesi) penggunaan tanah adat untuk perkebunan dan ijin usaha pertambangan tanpa melibatkan partisipasi masyarakat hukum adat dalam pemberian ijin tersebut. ${ }^{1}$

Persoalan hukum bagi masyarakat hukum adat seringkali muncul ketika hak-hak yang melekat padanya tidak mampu dilindungi oleh hukum negara.Hak-hak masyarakat hukum adat yang selama ini samar tercantum dan tersebar dalam berbagai peraturan-perundang-undangan, dalam kenyataannya hak mereka juga terabaikan dalam pelaksanaan pembangunan yang ada selama ini. Mengangkat dan mengimplementasikan kembali hakhak masyarakat hukum adat ini dari berbagai pandangan yang menginginkan hak-hak masyarakat hukum adat merupakan keharusan. ${ }^{2}$

\footnotetext{
${ }^{1}$ Dian Cahyaningrum: Pemanfaatan Tanah Adat, Jurnal , NEGARA HUKUM: Vol. 3, No. 1, Juni 2012, h.22

${ }^{2}$ BPHN, Pengkajian Hukum Tentang Perlindungan Hukum Bagi Masyarakat Adat Di Daerah Perbatasan, tanggal 1 April 2011, h.12
} 
Di antara kawasan perbatasan Kalimantan Utara yang sering mendapat perhatian banyak kalangan adalah kawasan perbatasan negara yang terletak di Kabupaten Nunukan dan Kabupaten Malinau dimana sebagian besar wilayah dimaksud dihuni oleh Masyarakat Hukum Adat Berbagai kebijakan telah diformulasikan dan diimplementasikan baik oleh pemerintah pusat maupun oleh pemerintah provinsi Kalimantan Utara sebagai upaya untuk mengembangkan dan meningkatkan kualitas pembangunan di daerah perbatasan Provinsi Kalimantan Utara namun belum menunjukkan keberpihakan kepada perlindungan hak-hak masyarakat hukum adat.

\section{Metode Penelitian}

Penelitian ini merupakan penelitian secara deskriptif-analitis dengan jalan menggambarkan secara rinci, sistimatik, dan menyeluruh mengenai segala hal yang berhubungan model pembangunan kawasan perbatasan dalam kaitanya dengan keberpihakan kepada MHA di wilyah perbatasan Kalimantara Utara. Kemudian, dilakukan analisis terhadap aspek hukum yang berkaitan dengan tanggungjawab negara terhadap masalah-masalah pembangunan yang ada, serta kendala-kendala yang dihadapi dalam pelaksanaanya. Menggunakan data sekunder yang diperoleh dari bahan hukum primer dan bahan hukum sekunder, Sumber data dalam penelitian ini adalah Pemerintah Daerah, dan DPRD, Badan Nasional Pengelolaan Perbatasan, dan MHA yang ada di di Provinsi Kalimantan Utara.

\section{Pembahasan}

\section{Karakteristik Permasalahan Kawasan Perbatasan Provinsi Kalimantan Utara Dan Implikasinya Kepada Masyarakat Hukum Adat.}

Permasalahan yang terjadi di kawasana perbatasan antar negara sangat kompleks, mulai dari permasalahan persepsi cara pandang terhadap perbatasan antar negara, permasalahan fisik, permasalahan infrastruktur pendukung, permasalahan sosial ekonomi masyarakat di kawasan perbatasan antar negara, sampai dengan permasalahan kesepakatan antar negara. Oleh karena itu di dalam penanganan permasalahan perbatasan harus bersifat komprehensif (terpadu) dimulai adanya kesepakatan antar 
negara melalui perundingan internasional, dan juga penyamaan persepsi terhadap kawasan perbatasan antar negara, baru selanjutnya penanganan permasalahan lainnya.

Pembangunan kawasan perbatasan di Kalimantan Utara merupakan bagian integral dari pembangunan kawasan perbatasan secara nasional. Wilayah perbatasan di kalimantan Utara ini memiliki potensi sumber daya alam yang cukup besar, serta merupakan wilayah yang sangat strategis bagi pertahanan dan keamanan negara. Namun secara umum pembangunan wilayah perbatasan masih jauh tertinggal dibandingkan dengan pembangunan di wilayah negara tetangga. Kondisi sosial dan ekonomi masyarakat yang tinggal di daerah ini umumnya jauh lebih rendah dibandingkan dengan kondisi sosial ekonomi warga negara tetangga. Hal ini telah mengakibatkan timbulnya berbagai kegiatan ilegal di daerah perbatasan yang dikawatirkan dalm jangka panjang dapat menimbulkan berbagai kerawanan sosial.

Mengacu pada Rencana Pembangunan Jangka Panjang Nasional (RPJPN) 20052025, pembangunan perbatasan bertujuan untuk "Mempercepat pembangunan kawasan perbatasan di berbagai bidang sebagai beranda depan negara dan sebagai pintu gerbang aktivitas ekonomi dan perdagangan dengan negara tetangga secara terintegrasi dan berwawasan lingkungan untuk meningkatkan kesejahteraan masyarakat dan menjamin pertahanan keamanan nasional" (RPJP 2005-2025). Untuk mewujudkan Kawasan perbatasan sebagai beranda depan negara yang terintegrasi dengan kawasan pusat pertumbuhan memerlukan kebijakan yang jelas, perencanaan yang sistematik dan orientasi jangka panjang, pelaksanaan secara terpadu dan pengendalian yang efektif.

Kemiskinan Masyarakat hukum adat menjadi permasalahan yang terjadi di kawasan perbatasan Kalimantan Utara. Hal ini dapat dilihat dari tingginya jumlah keluarga prasejahtera di kawasan perbatasan serta kesenjangan sosial ekonomi dengan masyarakat di wilayah perbatasan negara tetangga. Hal ini disebabkan oleh akumulasi berbagai faktor, seperti rendahnya mutu sumberdaya manusia, minimnya infrastruktur pendukung, 
rendahnya produktifitas masyarakat dan belum optimalnya pemanfaatan sumberdaya alam di kawasan perbatasan.

Hal yang senada dikemukakan oleh Sri Rum Giyarsih ${ }^{3}$ bahwa penyebab kemiskinan di Kabupaten Nunukan (salah satu Kabupaten di Kalimantan Utara yang berbatasan dengan Malaysia.) adalah minimnya/kurangnya natural assets, human assets, physical assets, financial assets, dan social assets. Natural assets atau aset sumber daya alam misalnya lahan dan air. Kaum miskin biasanya memiliki luas lahan yang terbatas. Human assets kaum miskin menyangkut kualitas sumberdaya manusia (pendidikan dan pengetahuan, keterampilan,, derajat kesehatan, penguasaan teknologi) yang relatif rendah. Physical assets kaum miskin misalnya minimnya akses ke jaringan infrastruktur dan fasilitas sosial ekonomi, jaringan listrik, jaringan jalan, dan komunikasi. Kaum miskin juga kekurangan akan financial assets yang berupa tabungan (saving) serta akses untuk memperoleh modal usaha. Kelompok ini juga kekurangan social assets yang berupa networking, kontak, dan pengaruh politik.

Kehidupan masyarakat hukum adat di kawasan perbatasan yang miskin infrastruktur dan tidak memiliki aksesibilitas yang baik, pada umumnya sangat dipengaruhi oleh kondisi sosial ekonomi di negara tetangga. Kehidupan sosial ekonomi masyarakat di kawasan perbatasan di Kalimantan Utara pada umumnya berkiblat ke wilayah negara tetangga. Hal ini disebabkan adanya infrastruktur yang lebih baik atau pengaruh sosial ekonomi yang lebih kuat dari wilayah negara tetangga. Secara jangka panjang, adanya kesenjangan pembangunan dengan negara tetangga tersebut berpotensi untuk mengundang kerawanan di bidang sosial politik. Misalnya berpindah kewarganegaraan, diperalat oleh sindikat penjahat internasional seperti kurir Narkoba antara negara, dan kegiatan illegal lainnya.

Dalam konteks penyebab kemiskinan pada masyarakat hukum adat di kawasan perbatasan, dari beberapa kekurangan aset tersebut, nampaknya kekurangan human assets, physical assets, dan social assets merupakan

\footnotetext{
${ }^{3}$ Sri Rum Giyarsih, Pengentasan Kemiskinan Yang Komprehensif Di Bagian Wilayah Terluar Indonesia - Kasus Kabupaten Nunukan Provinsi Kalimantan Utara, jurnal, Manusia Dan Lingkungan, Vol. 21, No.2, Juli 2014: 239-246
} 
kekurangan aset yang dapat diatasi dalam rangka pengentasan kemiskinan. Kekurangan human assets dapat diatasi dengan peningkatan kualitas sumberdaya manusia (pendidikan dan pengetahuan, keterampilan, derajat kesehatan, dan penguasaan teknologi sebagai bentuk pemenuhan hak-hak konstitusional masyarakat hukum adat sebagai warga negara. Program peningkatan pendidikan, pengetahuan, dan keterampilan, serta penguasaan teknologi melalui kebijakan makro yang berupa pendidikan gratis 12 tahun. Dengan program tersebut maka diharapkan meningkatkan kwalitas sumber daya masyarakat hukum adat.

Permasalahan berikutnya bagi masyarakat hukum adat di kawasan perbatasan Provinsi Kalimantan Utara adalah minimnya sarana dan prasarana dibidang pendidikan dan kesehatan. Pendidkan dan Kesehatan merupakan hak asasi manusia dan sekaligus hak konstitusional setiap warga negara Indonesia.Dan ini merupakan unsur kesejahteraan yang harus diwujudkan sesuai dengan cita-cita bangsa Indonesia sebagaimana dimaksud dalam Pancasila dan UUD NRI 1945. Negara bertanggungjawab dalam dalam melaksanakan kewajiban konstitusionalnya dengan menyediakan sarana dan prasarana pendidikan dan kesehatan yang layak bagi masyarakat hukum adat di kawasan Perbatasan Kalimantan Utara.

Permasalahan berikutnya yang dialamai oleh masyarakat hukum adat di kawasan Perbatasan Provinsi Kalimantan Utara adalah ketersediaan prasarana dan sarana, baik sarana dan prasarana wilayah maupun fasilitas sosial ekonomi masih jauh dari memadai. Jaringan jalan dan angkutan perhubungan darat masih sangat terbatas, yang menyebabkan sulit berkembangnya kawasan perbatasan, karena tidak memiliki keterkaitan sosial maupun ekonomi dengan wilayah lain. Kondisi prasarana dan sarana komunikasi seperti pemancar atau transmisi radio dan televisi serta sarana telepon di kawasan perbatasan umumnya masih relatif minim. Terbatasnya sarana komunikasi dan informasi menyebabkan masyarakat hukum adat perbatasan lebih mengetahui informasi tentang negara tetangga daripada informasi dan wawasan tentang Indonesia. Ketersediaan sarana dasar sosial dan ekonomi seperti pusat kesehatan masyarakat, sekolah, dan pasar juga 
sangat terbatas. Hal ini menyebabkan kawasan perbatasan sulit untuk berkembang dan bersaing dengan wilayah negara tetangga.

Keterbatasan sarana prasarana pendukung. Kondisi transportasi antar wilayah di perbatasan masih belum mampu menjadi penopang kegiatan ekonomi masyarakat, dan ini disebabkan oleh minimnya prasarana transportasi darat, baik jalan, jembatan maupun kendaraan relatif sedikit. Di wilayah Kalimantan Utara, sulitnya aksesibilitas memunculkan kecenderungan masyarakat untuk berinteraksi dengan masyarakat di wilayah Serawak dan Sabah. Minimnya asksebilitas dari dan keluar kawasan perbatasan wilayah merupakan salah satu faktor yang turut mendorong orientasi masyarakat yang cenderung berkiblat aktivitas sosial ekonominya ke negara tetangga yang secara jangka panjang dikhawatirkan akan memunculkan degradasi nasionalisme masyarakat perbatasan

Eksploitasi sumber daya alam yang berlebihan berdampak pada kerusakan ekosistem alam dan hilangnya keanekaragaman hayati secara langsung berimplikasi kepada kehidupan sosial, budaya dan kualitas hidup masyarakat hukum adat di Kawasan Perbatasan Kalimantan Utara. Puluhan tahun perusahan pemegang ijin HPH mengeploitasi hutan secara besar-besar mengakibatkan kerusakan lingkungan yang luar biasa. Perusahaan perkebunan Kelapa Sawit mengkonversi ratusan bahkan ribuhan hektar hutan menjadi kebun sawit dan Perusahaan pertambangan mineral dan batubarapun mengeksplotasi sumber daya alam berupan mineral dan batu baru. Implikasi dari ekspltasi sumber daya yang berlebihan mengakibatkan kerusakan lingkungan fisik dan sosial

\section{Model Pembangunan Kawasan Perbatasan yang Berpihak Kepada Masyarakat Hukum Adat.}

Keberpihakan pemerintah untuk membangunan kawasan perbatasan negara diwujudkan dalam Undang-Undang Nomor 23 Tahun 2014 tentang Pemerintahan Daerah ini, dimana diatur bahwa selain pembagian kewenangan sebagaimana diatur dalam Undang-Undang Nomor 43 Tahun 2008 tentang Wilayah Negara, Pemerintah Pusat mempunyai kewenangan untuk: 
a. penetapan rencana detail tata ruang;

b. pengendalian dan izin pemanfaatan ruang; dan

c. pembangunan sarana dan prasarana kawasan. ${ }^{4}$

Sebagai tindak lanjut pelaksanaan kewenangan pemerintah pusat maka keluarlah Perpres Nomor 2 Tahun 2015 tentang Rencana Pembangunan Jangka Menengah Nasional 2015-2019 sebagai dasar penyusunan rencana kerja pemerintah dan telah mengakomodasi Nawacita Ketiga, yaitu membangun Indonesia dari Pinggiran dengan memperkuat daerah-daerah dan desa dalam kerangka negara kesatuan.

Dari aspek perundang-undangan di bidang penataan ruang, UndangUndang Nomor 26 tahun 2007 tentang Penataan Ruang jo. PP Nomor 26 Tahun 2007 tentang Rencana Tata Ruang Wilayah Nasional (RTRWN) sebagaimana telah diubah dengan PP Nomor 13 Tahun 2017 telah mengamanatkan bahwa kawasan perbatasan negara adalah termasuk dalam kawasan strategis nasional (yaitu wilayah yang penataan ruangnya diprioritaskan karena mempunyai pengaruh sangat penting secara nasional terhadap kedaulatan negara, pertahanan dan keamanan negara, ekonomi, sosial, budaya, dan/atau lingkungan, termasuk wilayah yang telah ditetapkan sebagai warisan dunia). Selanjutnya, penetapan dan pengaturan kawasan perbatasan negara yang merupakan bagian kawasan strategis nasional tersebut ditetapkan dengan Peraturan Presiden.

Perpres Nomor 11 Tahun 2017 tentang Rencana Tata Ruang Kawasan Perbatasan Negara di Provinsi Sulut, Provinsi Gorontalo, Provinsi Sulteng, Provinsi Kaltim, dan Provinsi Kaltara. Penetapan Perpres 11 Tahun 2017 ini semakin menegaskan bahwa Pemerintah memiliki komitmen dan konsistensi dalam mewujudkan nawacita Presiden Jokowi yaitu membangun Indonesia dari Pinggiran, dan menjadikan kawasan perbatasan negara sebagai beranda depan negara. Selain dari itu, Perpres 11 Tahun 2017 ini diharapkan menjadi acuan serta dilaksanakan secara sungguh-sungguh, untuk semakin

\footnotetext{
${ }^{4}$ Lihat Pasal 361 ayat (3) Undang-Undang No. 23 Tahun 2014
} 
mewujudkan kedaulatan NKRI, karena negara ini milik bersama dan harus dipertahankan keutuhan wilayahnya dari Sabang sampai Merauke.

Berdasarkan uraian diatas dapat dipahami bahwa pembangunan kawasan perbatasan di Provinsi Kalimantan Utara adalah bagian integral dari pembangunan Nasional. Kawasan Perbatasan di Provinsi Kalimantan Utara khusunya perbatasan wilayah darat dengan Malaysia dihuni oleh masyarakat hukum adat. Keberadaan masyarakat hukum adat tidak saja telah mendapatkan perlindungan secara yuridis konstitusional sebagaimana diatur dalam Pasal 18B ayat (2), bahwa Negara mengakui dan menghormati kesatuan-kesatuan masyarakat hukum adat beserta hak-hak tradisionalnya sepanjang masih hidup dan sesuai dengan perkembangan masyarakat dan prinsip Negara Kesatuan Republik Indonesia yang diatur dalam undangundang".

Masyarakat hukum adat memiliki hubungan yang kuat dengan wilayah tempat mereka tinggal. Keterkaitan dengan tanah wilayahnya merupakan aspek yang tidak hanya dinilai secara ekonomi atau politis tapi juga mempunyai daya mistis yang masuk dalam kehidupan budaya dan spritual mereka ${ }^{5}$ Keterisolilasian kawasan perbatasan negara merupakan isu utama perbatasan, karena keterbatasan infrastruktur dasar wilayah, yaitu transportasi, energi (listrik dan BBM), komunikasi dan informasi, menyebabkan lambannya pertumbuhan ekonomi, dan minimnya pelayanan sosial dasar, khususnya pendidikan dan kesehatan. Niat baik Pemerintah dalam melaksanakan Pembangunan dalam rangka mengatasi permasalahn di kawasan perbatasan Provinsi Kalimantan Utara yang dihuni oleh masyarakat hukum adat belum tentu berpihak kepada masyarakat hukum adat bahkan bisa sebaliknya pembangunan tersebut justru tidak mendatangkan manfaat apa-apa kepada MHA,. Sebuah model pembangunan dikatakan berpihak pada MHA apabilah pembangunan itu didasarkan pada prinsip persetujuan awal tanpa paksaan, pembangunan yang berbasis kearifan lokal, pembangunan

\footnotetext{
${ }^{5}$ Putra Aditya, Hikmahanto Juwana dan Hadi Rahmat Purnama, Perlindungan Terhadap Masyarakat Huku Adat yan dipisahkan oleh Batas Negara, Tinjauan atas Praktik Amerika Serikat,Norwegia dan Indonesia, Artikel,FH Universitas Indonesia,Depok 2014,h. 2
} 
yang dapat memenuhi kebutuhan dasar masyarakat hukum adat, dan pembangunan yang berkelanjutan dan berwawasan lingkungan.

\section{Pembangunan Yang Didasarkan Pada Prinsip Persetujuan Awal Tanpa Paksaan}

Salah satu hak MHA adalah hak atas pembangunan. Hal ini sejalan dengan Peraturan Daerah Kabupaten Nunukan Nomor 16 Tahun 2018 Tentang Pemberdayaan Masyarakat Hukum Adat Pasal 8 yang menjelaskan Masyarakat Hukum Adat memiliki hak:

a. Hak atas tanah, wilayah dan sumber daya alam;

b. Hak atas pembangunan;

c. Hak atas spiritualitas dan kebudayaan;

d. Hak atas lingkungan hidup; dan

e. Hak untuk menjalankan hukum dan Peradilan Adat

Pembangunan merupakan kata kunci bagi perbaikan kondisi di wilayah perbatasan Kalimantan Utara. Pembangunan merupakan sebuah keniscayaan yang harus dilakukan oleh setiap negara menuju kesejahteraan masyarakat secara menyeluruh. Oleh karena itu konsentrasi implementasi program pembangunan nasional tidak hanya berkutat di daerah perkotaan, tetapi juga diorientasi ke daerah perbatasan ${ }^{6}$ Namun demikian model pembangunan diperkotaan belum tentu menunjukkan keberpihakan kepada MHA yang masih kental dengan adat istiadatnya sendiri. Oleh karena itu setiap pemabanguan di wilayah MHA harus didasarkan pada prinsip persetujuan atas dasar informasi di awal tanpa paksaan. Prinsip ini mengacu pada prinsip bahwa MHA memiliki hak untuk memberikan atau tidak memberikan persetujuan untuk tindakan yang akan mempengaruhi mereka, terutama tindakan yang mempengaruhi tanah, wilayah dan sumber tradisonal mereka. ${ }^{7}$

\footnotetext{
${ }^{6}$ Sonny Sudiar, Pembangunan Wilayah Perbatasan Negara: Gambaran Tentang Strategi Pengelolaan Kawasan Perbatasan Darat di Provinsi Kalimantan Utara, Jurnal Administrative Reform, Vol.3 No.4,Oktober-Desember2015,h.489

7 Marthen B Salinding, Prinsip Hukum Pertambangan Mineral dan Batubara yang Berpihak Kepada Masyarakat Hukum Adat Jurnal Konstitusi, Volume 16, Nomor 1, Maret 2019, h.137
} 
Prinsip ini terkait dengan hak MHA untuk bebas menerima atau menolak proyek pembangunan dalam wilayah mereka (free, prior, and informed consent) inilah hak yang paling banyak diperjuangkan dan dituntut oleh masyarakat hukum adat. Prinsip Persetujuan atas dasar informasi di awal tanpa paksaan (FPIC) menegaskan bahwa masyarakat adat mempunyai hak untuk secara bebas menyatakan "menerima" atau "menolak" sebuah rencana pembangunan dalam wilayah mereka atas dasar informasi yang lengkap yang disampaikan atau diperoleh MHA sejak sedini rencana itu dicetuskan. .

Prinsip persetujuan awal tanpa paksaan selaras Pasal 11 Peraturan Daerah Kabupaten Nunukan Nomor 16 Tahun 2018 Tentang Pemberdayaan Masyarakat Hukum Adat yang menjelaskan bahwa;

Hak atas pembangunan sebagaimana dimaksud dalam Pasal 8 huruf b meliputi:

a. Hak menentukan dan mengembangkan sendiri bentuk pembangunan yang sesuai dengan kebutuhan dan kebudayaan setempat;

b. Hak terlibat dalam pelaksanaan program pembangunan yang berada dalam wilayah masyarakat hukum adat sesuai dengan mekanisme adat;

c. Hak untuk mendapatkan informasi yang lengkap dan akurat mengenai program pembangunan yang ditawarkan oleh pemerintah dan pihak lain di luar pemerintah yang akan berdampak luas pada tanah, wilayah, sumber daya alam dan budaya setempat; dan

d. Hak untuk menolak bentuk pembangunan yang dinilai tidak sesuai dengan kebutuhan dan budaya adat setempat.

Terkait dengan pembangunan di Kawasan Perbatasan Provinsi Kalimantan Utara, berarti bahwa setiap pihak yang akan menyelenggarakan proyek pembangunan dalam wilayah MHA wajib memberikan informasi yang sejelas-jelasnya tentang seluruh aspek pembangunan itu, termasuk dampak baik dan buruk kepada MHA. MHA mempunyai hak untuk mendapatkan waktu yang cukup untuk mendiskusikan semua informasi tersebut dan berhak untuk mendapatkan nasihat atau bantuan dari pihak-pihak yang mereka inginkan dengan 
bahasa yang mereka pahami. Hal ini penting mengingat perbedaan sistem nilai, cara pikir dan pandangan hidup antara mereka dengan pihak luar.

Persetujuan atas dasar informasi di awal tanpa paksaan dapat dijelaskan secara sederhana sebagai hak MHA untuk mendapatkan informasi sebelum sebuah program pembanguan dilaksanakan dalam wilayah MHA, dan berdasarkan informasi tersebut, MHA secara bebas tanpa tekanan merumuskan keputusan untuk menyatakan setuju atau menolak. Keseluruhan ini berarti bersikap adil (fair) terhadap MHA. ${ }^{8}$ Prinsip di atas terkait pula dengan posisi MHA sebagai subjek pembanguan dan bukan sebagai objek pembanguan sehingga MHA menjadi korban pembangunan.

Berdasarkan uraian di atas dapat disimpulkan bahwa salah satu model pembangunan kawasa perbatasan Provinsi Kalimantan Utara adalah pembangunan dengan prinsip persetujuan atas dasar informasi di awal tanpa paksaan. Prinsip ini mengacu pada prinsip bahwa MHA memiliki hak untuk memberikan atau tidak memberikan persetujuan untuk tindakan yang akan mempengaruhi mereka, terutama tindakan yang mempengaruhi tanah, wilayah dan sumber tradisonal mereka.Setiap pembangunan yang akan dilaksanakan diwilayah MHA, merelah yang menentukan apakah mereka menerima atau menolak. Prinsip ini juga telah memposisikan MHA sebagai subjek pembangunan bukan sebagai objek pembangunan.

\section{Pembangunan Yang Berbasis Kearifan Lokal.}

Seringkali pembangunan dipandang secara keliru, dengan menganggap bahwa pembangunan merupakan perubahan-perubahan nilai, pembangunan gedung-gedung mewah, bahkan transformasi dari masyarakat tradisional ke masyarakat modern. Namun, pembangunan yang baik adalah pembangunan yang berakar dan mempertimbangkan dengan seksama nilai-nilai lokal yang ada dalam masyarakat. Kearifan lokal adalah dasar untuk pengambilan kebijakan pada level lokal di bidang kesehatan, pertanian, pendidikan, dan pengelolaan sumber daya alam.

\footnotetext{
${ }^{8}$ Ibid
} 
Pembangunan sebagai suatu proses pada hakekatnya merupakan pembaharuan yang terencana dan dilaksanakan dalam tempo yang relatif cepat. Berbagai pembaharuan yang telah dilakukan membawa kita pada kemajuan ilmu pengetahuan dan teknologi, pertumbuhan ekonomi dan kecanggihan sarana komunikasi. Kearifan lokal sangat erat kaitannya dengan masyarakat, karena segala sesuatu yang terdapat dalam masyarakat dipengaruhi oleh kebudayaan yang dimiliki masyarakat itu sendiri. Oleh karena itu sepatutnya pembangunan dalam masyarakat harus beriringan dengan kearifan lokal yang ada.

Untuk mengetahui kearifan lokal di suatu wilayah maka kita harus bisa memahami nilai-nilai budaya yang baik yang ada di dalam wilayah tersebut. Nilai-nilai kearifan lokal ini sudah diajarkan secara turun temurun oleh orang tua kepada anak-anaknya, Karena kearifan lokal merupakan nilai-nilai yang baik dan telah diyakini oleh masyarakat secara turun temurun, maka mengenali unsur-unsur kearifan lokal suatu masyarakat sangat penting dalam proses pemberdayaan dan pembangunan bagi mereka.

Pembangunan di Kawasan Perbatasan Kalimantan Utara khususnya perbatasan yang masyarakatnya masih dalam bentuk masyarakat hukum adat merupakan sebuah keharusan atau keniscayaan. Suatu keharusan yang tidak saja hanya secara retorika, tetapi harus ada sinergitas antara pemerintah pusat dengan pemerintah daerah.

Kabupaten Nunukan dan Kabupaten Malinau adalah dua Kabupaten di Provinsi Kalimantan Utara yang berbatasan darat dengan Malaysia. Ada 7 (tujuh) kecamatan di Kabupaten Nunukan yang berbatasan darat dengan Malaysia yaitu Kecamatan Krayan, Kecamatan Krayan Selatan, Kecamatan Lumbis, Kecamatan Lumbis Ogong, Kecamatan Sebuku, Kecamatan Sei Manggaris dan Kecamatan Tulin Onsoi. Sementara Kabupaten Malinau kecamatan yang berbatasan dengan Malaysia adalah Kecamatan Pujungan, Kecamatan Kayan Huku,Kecamatan Kayan Hilir, Kecamatan Kayan Selatan dan Kecamatan Bahau Hulu. Semua Kecamatan yang disebutkan diatas masyarakatnya masih dalam bentuk masyarakat 
hukum adat. Oleh karena itu pembangunan kawasan perbatasan di Provinsi Kalimantan Utara yang berbatasan darat dengan Malaysia berarti membangunan masyarakat hukum adat, sehingga pembangunan kawasan perbatasan tidak merusak nilai nilai yang ada dalam masyarakat hukum adat, melainkan berbasis kepada kearifan lokal masyarakat hukum adat.

Marthin Labo menyatakan bahwa kearifan local adalah pandangan hidup dan ilmu pengetahuan serta berbagai strategi kehidupan yang berwujud aktivitas yang dilakukan oleh masyarakat local dalam menjawab berbagai masalah dalam pemenuhan lebutuhan mereka. Lebih lanjut dikatakan bahwa model pembangunan di daerah belum tentu cock dan diterimah oleh masyarakat hukum adat di Kawasan perbatasan Kalimantan utara, karena buadaya dan pandangan hidup setiap kelompok masyarakat berbeda-beda. ${ }^{9}$

Labih lanjut Marthin Labo menjelaskan bahwa dalam kearifan lokal, masyarakat hukum adat bereksistensi, dan berkoeksistensi satu dengan yang lain. Rekontruksi kearifan lokal masyarakat hukum adat harus dijadikan dasar dalam membangun wilayah perbatasan, sehingga nilainilai luhur itu tidak meredup, memudar dan kehilangan makna substantifnya. Lalu yang tertinggal hanya kulit permukaan semata, menjadi simbol yang tidak ada artinya. Pemerintah pusat maupun pemerintah Daerah harus prioritaskan pembangunan wilayah perbatasan tanpa menghilangkan kearifan lokal sebagai kekayaan budaya dan identitas masyarakat hukum adat. ${ }^{10}$

Berdasarkan uraian di atas dapat dijelaskan bahwa kearifan local merupakan bagian dari system budaya, biasanya berupa laranganlarangan (tabu-tabu) yang mengatur hubungan manusia dengan lingkungan alamnya. Kearifan local berfungsi untuk menjaga kelestarian dan kesinambungan aset yang dimiliki suatu masyarakat sehingga masyarakat dapat terpenuhi kebutuhan-kebutuhannya dari generasi ke generasi berikutnya, tanpa harus merusak atau menghabiskan aset

\footnotetext{
${ }^{9}$ Marthin Labo, Tokoh Adat Masyarakat Hukum Adat Kabupaten Malinau,wawancara tanggal 6 Agustus 2019

${ }^{10}$ Ibid
} 
tersebut. Oleh sebab itu, kearifan local selalu dijadikan pedoman atau acuan oleh masyarakat dalam bertindak atau berperilaku dalam praksis kehidupannya.

Dengan demikian dapat disimpulkan bahwa salah satu model pembangunan kawasan perbatasan yang berpihak kepada masyarakat hukum adat adalah pembangunan yang berbasis kearifan lokal, yaitu pembangunan yang tidak merusak nilai-nilai sosial budaya masyarakat hukum adat, pembangunan yang tidak menghilangkan identitas masyarakat hukum adat, dan pemabngunan yang tidak menyebabkan masyarakat hukum adat tercabut dari akar budayanya.

\section{Pembangunan Yang Dapat Memenuhi Kebutuhan Dasar Masyarakat} Hukum Adat

Tujuan utama pembangunan adalah meningkatkan kesejahteraan masyarakat dimana pembangunan itu dilaksanakan. Demikian pula pembanguan yang silaksanakan di kawasan Perbatasan Kalimantan Utara dalam wilayah MHA sejatinya memberikan peningkatan kesejahteraan terhadap MHA dengan terpenuhinya kebutuhan dasar MHA.

Jaminan kesejahteraan MHA telah menjadi perhatian serius dalam pembangunan di Indonesia. MHA telah menjadi prioritas pembanguan sebagaimana tertuang dalam Rencana Pembangunan Jangka Menengah Nasional (RPJMN). Pemerintah Indonesia mempunyai basis hukum yang kuat untuk merealisasikan perlindungan sosial terhadap MHA. Hal ini mengafirmasi bahwa kesatuan masyarakat hukum adat beserta hak-hak tradisionalnya diakui dan dihormati oleh negara. Pasal 18 B ayat (2) UUD 1945 yang dikutip di atas menjamin semua MHA di Indonesia termasuk MHA di kawasan Perbatasan Kalimantan Utara.

Sementara itu, sebagaimana disebutkan dalam Pasal 28I ayat (3) UUD 1945, "Identitas budaya dan hak masyarakat tradisional dihormati selaras dengan perkembangan zaman dan peradaban." Pernyataanpernyataan tersebut merupakan ketetapan resmi yang memperlihatkan bahwa tidak satupun kelompok MHA yang dilupakan atau boleh tertinggal dalam proses pembangunan. Berkenaan dengan hal tersebut, Indonesia 
terikat pada komitmen internasional tentang pengakuan hak-hak MHA. Pada 13 September 2007 Pemerintah Indonesia ikut menandatangani deklarasi United Nation Declaration on The Rights of Indigenous Peoples (UNDRIP) yang mengamanatkan bahwa Masyarakat Adat memiliki hak yang sama terkait penghidupan, pendidikan, mempertahankan identitas, dan bebas dari segala bentuk diskriminasi

Program pemberdayaan MHA merupakan prioritas pembangunan yang tertuang dalam Rencana Pembangunan Jangka Menengah Nasional (RPJPN) 2005- 2025, khususunya di prioritas nomor 10 tentang Daerah Tertinggal, Terdepan, Terluar, dan Pasca Konflik. Sasaran yang ingin dicapai adalah terpenuhinya kebutuhan dasar, aksesibilitas dan pelayanan sosial dasar bagi warga Komunitas MHA. Indikator capaian dalam RPJMN tersebut antara lain berupa tersedianya permukiman dan infrastruktur, pemberian bantuan jaminan hidup, bantuan peralatan kerja, dan bimbingan sosial.

Secara umum, kebijakan yang dilakukan untuk mencapai sasaran pembangunan daerah tertinggal adalah dengan mengembangkan perekonomian lokal di daerah tertinggal, penguatan kelembagaan masyarakat dan pemerintah daerah dalam pengelolaan sumber daya lokal, peningkatan pelayanan kesehatan yang berkualitas dan terjangkau, peningkatan layanan pendidikan yang berkualitas, peningkatan sarana prasarana infrastruktur, peningkatan aksesibilitas dengan pusat-pusat pertumbuhan, serta mendorong pembiayaan yang lebih memihak kepada daerah tertinggal.

Pembangunan wilayah MHA termuat dalam RPJPN 2005 - 2025 bidang wilayah dan tata ruang, namun:

a) Pemberdayaan belum mengacu pada program yang berkelanjutan.

b) Prioritas/koordinasi lintas sektor dan dukungan Pemda untuk wilayah MHA hampir tidak ada. 
c) Sedikitnya penelitian/evaluasi tentang pemberdayaan MHA (pelayanan, pendamping dan persepsi penerima bantuan, serta dampak terhadap peningkatan kesejahteraan masyarakat).

d) Kepedulian dan kontribusi masyarakat (LSM, organisasi sosial, dunia usaha, dan media masa) sangat terbatas.

e) Berbagai gap target pembangunan (kemiskinan, MDGs, ketahanan nasional) diantaranya terdapat di wilayah MHA.

Pemberdayaan MHA, adalah proses pembangunan untuk memfasilitasi dan mendorong Masyarakat Hukum Adat agar mampu menempatkan diri secara proporsional dan menjadi pelaku utama dalam memanfaatkan sumber daya alam dan lingkungan.

Berdasarkan uraian di atas dapat disimpulkan bahwa salah model pembangunan di kawasan perbatasan Kalimantan Utara yang berpihak kepada MHA adalah model pembangunan yang dapat memenuhi kebutuhan dasar MHA yaitu pangan,sandang dan papan, aksesibilitas dan pelayanan sosial dasar bagi MHA. Indikator capaian tersebut antara lain berupa tersedianya permukiman dan infrastruktur, pemberian bantuan jaminan hidup, bantuan peralatan kerja, dan bimbingan sosial.

\section{Pembangunan Yang Berkelanjutan dan berwwaasan Lingkungan.}

Pembangunan dan lingkungan memiliki hubungan yang saling berkaitan, timbal balik dan memiliki interaksi yang sangat erat. Tidak dapat dipungkiri, bahwa pembangunan dapat mempengaruhi lingkungan dan lingkungan pun dapat mempengaruhi pembangunan. Serta keduanya saling berkaitan dan saling berhubungan. Namun, keduanya baik pembangunan dan lingkungan belum tentu dapat saling mendukung. Karena mungkin saja pembangunan yang kurang optimal sehingga menciptakan lingkungan yang kurang kondusif dan dapat pula lingkungan yang kurang mendukung, dalam hal ini lingkungan yang negatif ${ }^{11}$

Menurut Kristian Muned pembangunan berkelanjutan dan berwawasan lingkungan pada dasarnya adalah suatu upaya pembangunan

11 M. Zaini1, Agus Tri Darmawanto, Implementasi Pembangunan Berkelanjutan Berwawasan Lingkungan Studi Pada Kelurahan Lempake Kecamatan Samarinda Utara Kota Samarinda, JIEP-Vol. 15, No 2 November 2015 ISSN (P) 1412-2200 E-ISSN 2548-1851,h.1 
yang berjalan berkesinambungan atau pembangunan berkelanjutan.(sustainable development) adalah suatu proses pembangunan yang memanfaatkan sumber daya alam dan sumber daya manusia sebesar-besarnya, dengan menyerasikan sumber daya alam dengan manusia sebagai subjek dan objek dalam pembangunan. ${ }^{12}$ Kebijakan pembangunan Kawasan perbatasan Kalimantan Utara khususnya yang masuk dalam wilayah Administrasi Kabupaten Malinau berdasarkan pada prinsip pembangunan yang berkelanjutan dan berwawasan lingkungan.Pembangunan infransturktur dimaksudkan untuk kesejahteraan masyarakat khusunya MHA karena itu sebelum proyek pembangunan dimulai terlebih dahulu ada analisis dampak lingkungan (AMDAL). Lebih lanjut dijelaskan oleh Kristian Muned, pengelolaan sumber daya alam di wilayah Administrasi Kabupaten Malinau sebagai bagian dari pembangunan dalam rangka pemanfaatan sebesar-besarnya bagi bagi kemakmuran masyarakat, karena itu dalam pengelolaannya tidak mencemari dan merusak kelestarian lingkungan.

Sumber daya alam adalah hak tradisional MHA dan telah mendapat pengakuan dalam konstitusi khusunya dalam Pasal 18 B ayat (2) dan Pasal 28 I ayat (3) UUD NRI 1945. MHA memandang SDA sebagian yang tidak terpishkan dari kehidupannya. MHA memiliki kearifan lokal dalam memelihara keberlangsungan lingkungannya. Oleh karena itu ketika SDA yang secara konstitusional dikuasai oleh negara kemudian dilimpahkan kepada investor untuk kelola maka prinsip pengelolaan SDA berkelanjutan dan berwawasan lingkungan menjadi prioritas. Pengelolaan SDA dalam wilayah tanah adat dan berimplikasi pada perusakan dan pencemaran lingkungan sama dengan tindakan merampas kesejahteraan MHA karena itu dapat dikategorikan melanggar hak asasi MHA.

Berdasarkan uraian di atas dapat disimpulkan bahwa salah satu model pembangunan yang berpihak kepada MHA adalah pembangunan yang berwawasan lingkungan dan berkelanjutan ini diharapkan supaya dalam proses pembangunan memiliki kesadaran dan perencanaan

\footnotetext{
${ }^{12}$ Kristian Muned,Wakil Bupati Kabupaten Malinau bidang Ekonomi dan Pembangunan ,Wawancara tanggal 7 Agustus 2019
} 
pembangunan yang bijaksana. Kebijaksanaan yang dimaksud yaitu dalam menggunakan dan mengelola sumber daya alam secara baik untuk meningkatkan kualitas hidup dan lingkungan.

\section{Penutup}

\section{Kesimpulan}

a. Beberapa karakteristik permasalahan kawasan perbatasan Provinsi Kalimantan Utara dan implikasinya kepada Masyarakat Hukum Adat yaitu tingginya angka kemiskinan, minimnya sarana dan prasarana dibidang pendidikan dan kesehatan, ketersediaan prasarana dan sarana, baik sarana dan prasarana wilayah maupun fasilitas sosial ekonomi masih jauh dari memadai, Jaringan jalan dan angkutan perhubungan darat masih sangat terbatas yang menyebabkan sulit berkembangnya kawasan perbatasan, karena tidak memiliki keterkaitan sosial maupun ekonomi dengan wilayah lain,rendahnya mutu sumberdaya manusia, minimnya infrastruktur pendukung, rendahnya produktifitas masyarakat dan pemanfaatan sumberdaya alam di kawasan perbatasan yang tidak berpihak kepada MHA, aksesibilitas kawasan perbatasan terhadap kota-kota di Kalimantan sangat rendah. Implikasi lebih lanjut dari kondisi di kawasan perbatasan mendorong masyarakat terlibat dalam kegiatan-kegiatan ekonomi illegal guna memenuhi kebutuhan hidupnya. Hal ini selain melanggar hukum dan potensial menimbulkan kerawanan dan ketertiban juga sangat merugikan negara.

b. Beberapa model pembangunan di kawasan perbatasan Kalimantan Utara yang berpihak kepada Masyarakat hukum adat yakni;

1) Pembangunan yang didasarkan pada prinsip persetujuan awal tanpa paksaan, yaitu model pembangunan yang memposisikan masyarakat hukum adat sebagai subjek pembangunan sehingga MHA memeiliki hak untuk menerima atau menolak setiap pembangunan yang masuk ke wilayah mereka.

2) Pembangunan yang berbasis kearifan lokal. yaitu model pembangunan yang tidak merusak nilai-nilai sosial budaya 
masyarakat hukum adat, pembangunan yang tidak menghilangkan identitas masyarakat hukum adat, dan pemabngunan yang tidak menyebabkan masyarakat hukum adat tercabut dari akar budayanya.

3) Pembangunan yang dapat memenuhi kebutuhan dasar masyarakat hukum adat yaitu model pembangunan di kawasan perbatasan Kalimantan Utara yang dapat memenuhi kebutuhan dasar MHA yaitu pangan,sandang dan papan, aksesibilitas dan pelayanan sosial dasar bagi MHA

4) Pembangunan yang berwawasan lingkungan dan berkelanjutan yakni model pembangunan yang memiliki kesadaran dan perencanaan pembangunan yang bijaksana. Kebijaksanaan yang dimaksud yaitu dalam menggunakan dan mengelola sumber daya alam secara baik untuk meningkatkan kualitas hidup dan lingkungan.

\section{A. Saran}

1. Berbagai permasalahan klasis yang menderah Masyarakat Hukum Adat di kawasan perbatasan Kalimantan Utara dengan Malaysia menyebabkan mereka masih hidup dalam kemiskinan oleh karena itu pemerinah pusat maupun pemerintah daerah segera menyelesaikan permasalahan tersebut melalui pembangunan yang tetap menghargai kearifan lokal.

2. Tujuan akhir dari sebuah pembangunan kawasan perbatasan darat Provinsi Kalimantan Utara adalah memberikan kesejahteraan terhadap masyarakat hukum adat, oleh karena itu pemerintah dalam melaksanakan salah satu amanat konstitusi yaitu menyelenggarakan pembangunan memilih model pembangunan yang berpihak kepada masyarakat hukum adat.

\section{Buku}

\section{DAFTAR PUSTAKA}

Aditya, Putra, Hikmahanto Juwana dan Hadi Rahmat Purnama, Perlindungan Terhadap Masyarakat Huku Adat yan dipisahkan oleh Batas Negara, 
Tinjauan atas Praktik Amerika Serikat,Norwegia dan Indonesia, Artikel,FH Universitas Indonesia,Depok 2014,.

BAPPENAS. Evaluasi Pembangunan Kawasan Perbatasan 2005-2007

BPHN, Pengkajian Hukum Tentang Perlindungan Hukum Bagi Masyarakat Adat Di Daerah Perbatasan, tanggal 1 April 2011

Dian Cahyaningrum: Pemanfaatan Tanah Adat , Jurnal , NEGARA HUKUM: Vol. 3, No. 1, Juni 2012,

Djamanat Samosir. 2013, Hukum Adat Indonesia. Nuansa Aulia, Medan:,

Eleanor D. Kinney, 2012, “The International Human Right to Health”, dalam Indiana Law Review, Vol 34,

LP2KD Prov. Kaltara, Menuju Kesejahteraan Rakyat Kaltara 2014-2015

M. Zaini1, Agus Tri Darmawanto, Implementasi Pembangunan Berkelanjutan Berwawasan Lingkungan Studi Pada Kelurahan Lempake Kecamatan Samarinda Utara Kota Samarinda, JIEP-Vol. 15, No 2 November 2015 ISSN (P) 1412-2200 E-ISSN 2548-1851

Martua Sirait,at.al 2010, Bagaimana Hak-Hak Masyarakat Hukum Adat dalam Mengelola Sumber Daya Alam Diatur, Southeast Asia Policy Research Working Paper, No. 24.

Muladi, 2004,Sumbang Saran Perubahan UUD 1945, Yayasan Habibie Center, h. 63

Philip Pettitt (1991) menyebutkan 6 tipe unjustice dalam konteks justice and utility salah satunya adalah treating people unequally.

Salinding, Marthen B, Prinsip Hukum Pertambangan Mineral dan Batubara yang Berpihak Kepada Masyarakat Hukum Adat Jurnal Konstitusi, Volume 16, Nomor 1, Maret 2019,

Soerjono Soekanto, Pengantar Penelitian Hukum, Penerbit UI Press, 2006,

Sudiar, Sonny Pembangunan Wilayah Perbatasan Negara: Gambaran Tentang Strategi Pengelolaan Kawasan Perbatasan Darat di Provinsi Kalimantan Utara, Jurnal Administrative Reform, Vol.3 No.4,Oktober-Desember 2015,

Wicipto Setiadi, Sambutan Pembukan Kepala Badan Pembinaan Hukum Nasional pada Seminar Tentang Arah Perlindungan Hukum Bagi Masyarakat Adat Dalam Sistem Hukum Nasional, Malang, 12 Mei 2011 


\section{Peraturan Perundang-Undangan}

Undang-Undang Dasar Negara Republik Indonesia 1945.

Undang-Undang Nomor 39 Tahun 2009 Tentang Hak Asasi Manusia

Undang-Undang Nomor 36 Tahun 2009 Tentang Kesehatan

Undang-Undang Nomor 23 Tahun 2014 tentang Pemerintahan Daerah Undang-undang Nomor 6 Tahun 2014 Tentang 